\title{
High quality draft genome of Lactobacillus kunkeei EFB6, isolated from a German European foulbrood outbreak of honeybees
}

\author{
Marvin Djukic ${ }^{1}$, Anja Poehlein ${ }^{1}$, Juliane Strauß ${ }^{1}$, Fabian Jannik Tann ${ }^{1}$, Andreas Leimbach¹, Michael Hoppert ${ }^{2}$ \\ and Rolf Daniel ${ }^{1 *}$
}

\begin{abstract}
The lactic acid bacterium Lactobacillus kunkeei has been described as an inhabitant of fructose-rich niches. Here we report on the genome sequence of L. kunkeei EFB6, which has been isolated from a honeybee larva infected with European foulbrood. The draft genome comprises 1,566,851 bp and 1,417 predicted protein-encoding genes.
\end{abstract}

Keywords: Lactobacillus kunkeei, Lactic acid bacteria, European foulbrood, Honeybee, Cellular surface protein, Biofilm formation

\section{Introduction}

Honeybees are the most economically valuable pollinators of agricultural crops [1]. A disappearance of honeybees would result in an approximately $90 \%$ decrease in production of some fruits [2]. European foulbrood (EFB) and American foulbrood (AFB) are the two most important honeybee diseases affecting the brood [3]. While the AFB is caused by the spore-forming, Gram positive bacterium Paenibacillus larvae [4], EFB is caused by the capsuleproducing Melissococcus plutonius [5]. It has been shown that members of the lactic acid bacteria (LABs) inhibit the growth of M. plutonius [6] and P. larvae [7]. LABs are found in a variety of habitats, including human and animal microbiomes, and are used as food additives.

The honeybee crop microbiome consists of 13 bacterial species belonging to the genera Lactobacillus and Bifidobacterium [8]. These bacteria play a key role in the production of honey and bee bread. The latter serves as long-term food storage for adult honeybees and larvae. L. kunkeei is a common symbiont for Apis and the dominating $\mathrm{LAB}$ member in bees [6]. The organism is a specialist for colonization of the honeybee crop and

\footnotetext{
* Correspondence: rdaniel@gwdg.de

'Department of Genomic and Applied Microbiology \& Göttingen Genomics Laboratory, Institute of Microbiology and Genetics, Georg-August University of Göttingen, Göttingen, Germany

Full list of author information is available at the end of the article
}

interacts with the epithelial layer of the crop. L. kunkeei has been described as a fructophilic LAB [9]. Initially, it was isolated from wine [10], but it has also been found on flowers and in honey.

L. kunkeei EFB6 is the first LAB isolated from a German EFB-diseased larva. Here, we describe genomic features of this organism, focusing on factors that improve competition with bacteria such as M. plutonius and P. larvae. In addition, potential cell surface proteins that might play a role in cellular adhesion and biofilm formation are analyzed.

\section{Organism information}

In October 2012, an EFB outbreak in Bavaria (Germany) was confirmed. EFB-diseased larvae from this outbreak were collected, immediately frozen in liquid nitrogen and stored at $-80^{\circ} \mathrm{C}$ for further investigation. Several EFBinfected larvae were dissected under sterile conditions. To obtain LAB the guts of the larvae, which formed a yellow, glue-like slime, were suspended in MRS medium (Carl Roth GmbH \& Co KG, Karlsruhe, Germany) and subsequently streaked on solidified MRS to isolate single colonies. Strain L. kunkeei EFB6 (Table 1, Additional file 1: Table S1) was isolated from these agar plates after aerobic incubation at $35^{\circ} \mathrm{C}$.

L. kunkeei EFB6 is a non-sporulating, low G + C Gram positive member of the Lactobacteriaceae and taxonomically related to the genus Pediococcus. The strain exhibited 


\begin{tabular}{|c|c|c|c|}
\hline MIGS ID & Property & Term & Evidence code \\
\hline & Classification & Domain Bacteria & TAS [11] \\
\hline & & Phylum Firmicutes & TAS [12-15] \\
\hline & & Class Bacilli & TAS [16] \\
\hline & & Order Lactobacillales & TAS [17] \\
\hline & & Family Lactobacillaceae & TAS [18] \\
\hline & & Genus Lactobacillus & TAS [18-21] \\
\hline & & Species Lactobacillus kunkeei & TAS [10] \\
\hline & & strain: EFB6 & TAS (this study) \\
\hline & Gram stain & Positive & TAS [10] \\
\hline & Cell shape & Rod-shaped & IDA \\
\hline & Motility & Non-motile & IDA \\
\hline & Sporulation & Non-sporulating & NAS \\
\hline & Temperature range & Mesophile & TAS [10] \\
\hline & Optimum temperature & $30^{\circ} \mathrm{C}$ & NAS \\
\hline & $\mathrm{pH}$ range; Optimum & $4.5-6.2 ; 6$ & NAS \\
\hline & Carbon source & Varied & NAS \\
\hline MIGS-6 & Habitat & Honeybee larva & IDA \\
\hline MIGS-6.3 & Salinity & $5 \% \mathrm{NaCl}(\mathrm{w} / \mathrm{v})$ & TAS [10] \\
\hline MIGS-22 & Oxygen requirement & Facultative & IDA \\
\hline MIGS-15 & Biotic relationship & Host-associated & TAS [6] \\
\hline \multirow[t]{2}{*}{ MIGS-14 } & Pathogenicity & Non-pathogen & NAS \\
\hline & Biosafety level & 1 & TAS [22] \\
\hline MIGS-23 & Isolation & EFB-diseased honeybee larva & IDA \\
\hline MIGS-4 & Geographic location & Bavaria, Germany & IDA \\
\hline MIGS-5 & Sample collection & October 1, 2012 & IDA \\
\hline MIGS-4.1 & Latitude & $49^{\circ} 14^{\prime} \mathrm{N}$ & IDA \\
\hline MIGS-4.2 & Longitude & $11^{\circ} 05^{\prime} \mathrm{E}$ & IDA \\
\hline MIGS-4.4 & Altitude & $400 \mathrm{~m}$ a.s.l & IDA \\
\hline
\end{tabular}

a $100 \% 16 \mathrm{~S}$ rRNA gene nucleotide sequence identity to the type strain L. kunkeei YH-15 (Table 1, Figure 1). Cells harvested in exponential growth phase exhibited a length ranging from 0.7 to $1.3 \mu \mathrm{m}$ and a diameter ranging from 0.3 to $0.5 \mu \mathrm{m}$ as determined by transmission electron microscopy (TEM) of either negatively stained or ultrathin-sectioned samples (Figure 2). Preparations for ultrathin sectioning and negative staining of cells were performed as described by [23]. The L. kunkeei EFB6 cell wall is approximately $12 \mathrm{~nm}$ thick. This value is rather thin compared to cell walls of other Gram positives [24]. Three distinct wall layers of L. kunkeei EFB6 (two darker stained outer and inner layers and a brighter layer in between) could be distinguished by TEM. Surface layers and cellular appendages (pili, fimbriae) were not detected.

\section{Genome sequencing and annotation}

\section{Genome project history}

The organism was selected for sequencing on the basis of its use as potential inhibitor for the primary agents of AFB and EFB [6,7]. The aim was to investigate potential factors to increase bacterial competition fitness and cell surface proteins, which might be important for cellular adhesion and biofilm formation.

A summary of the project information is shown in Table 2.

\section{Growth conditions and DNA isolation}

To isolate genomic DNA L. kunkeei EFB6 was grown aerobically in $50 \mathrm{ml}$ MRS medium at $35^{\circ} \mathrm{C}$ with shaking at $150 \mathrm{rpm}$ (Lab-Therm Lab-Shaker, Adolf Kühner AG, Birsfelden, Switzerland). Cells were harvested in 


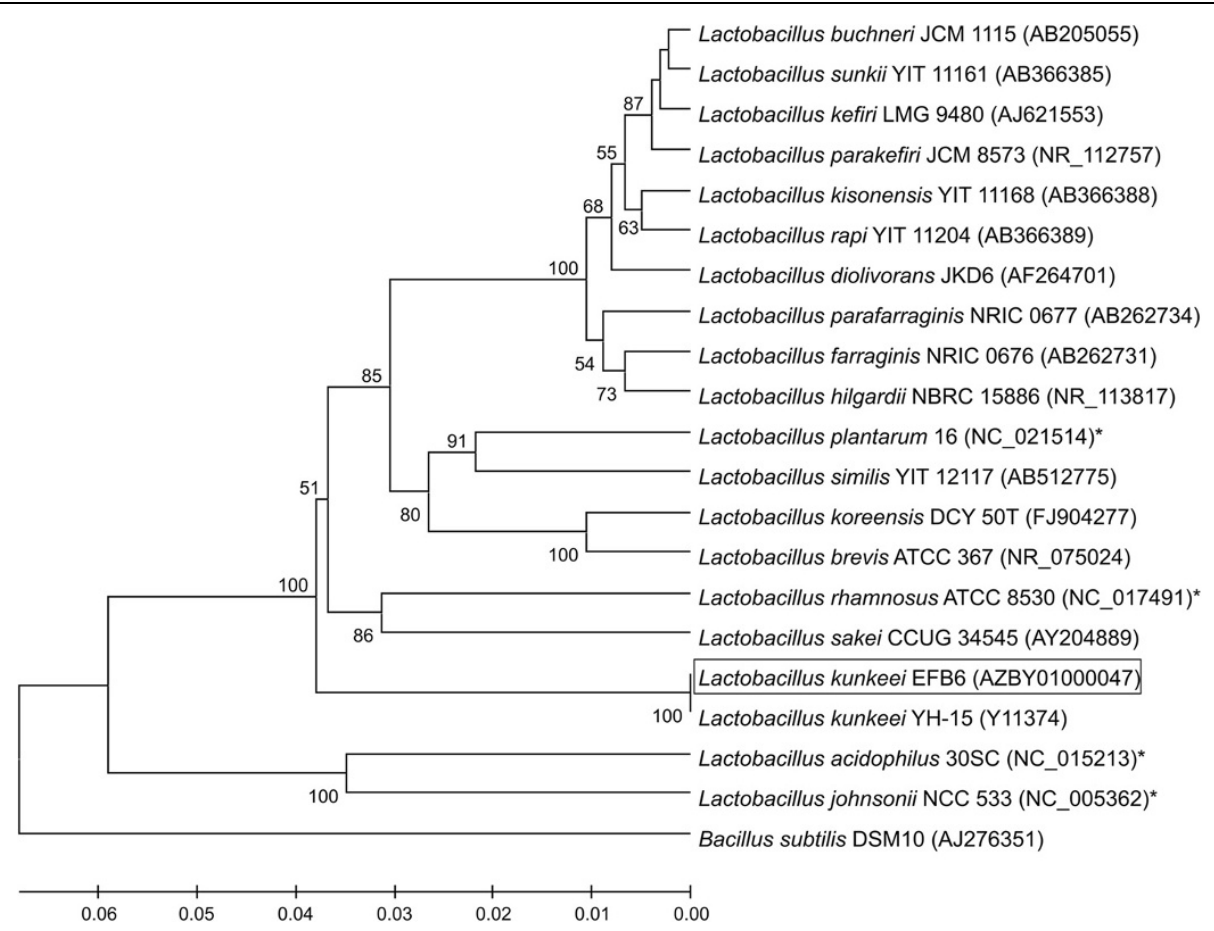

Figure 1 Phylogenetic tree highlighting the position of L. kunkeei EFB6 relative to other Lactobacillus strains based on 16S rRNA gene sequences. GenBank accession numbers are indicated in parentheses. Asterisks indicate that a consensus sequence was calculated from all $16 \mathrm{~S}$ rRNA gene sequences present in the corresponding genome. L. kunkeei EFB6 is boxed. Sequences were aligned using ClustalW 1.6 [25]. The phylogenetic tree was obtained by using the UPGMA method within MEGA 6.06 software [26]. Numbers at nodes are bootstrap values calculated from 1,000 resamplings to generate a majority consensus tree. Bacillus subtilis DSM10 was used as outgroup. The scale bar indicates the nucleotide sequence divergence.

exponential growth phase using a Beckman Coulter Allegra $^{\text {Tx }} \mathrm{X}-12 \mathrm{R}$ centrifuge (Beckman Coulter $\mathrm{GmbH}$, Krefeld, Germany) for 25 minutes at 2,750 $g$ and $4^{\circ} \mathrm{C}$. Genomic DNA was isolated using the Epicentre ${ }^{\circ}$ MasterPure $^{\mathrm{m}}$ DNA Purification kit (Epicentre, Madison, WI, USA).

\section{Genome sequencing and assembly}

Whole-genome sequencing of L. kunkeei EFB6 was performed by employing the Genome Analyzer II (Illumina, San Diego, CA). The shotgun library was prepared according to the manufacturer's protocols. For de novo

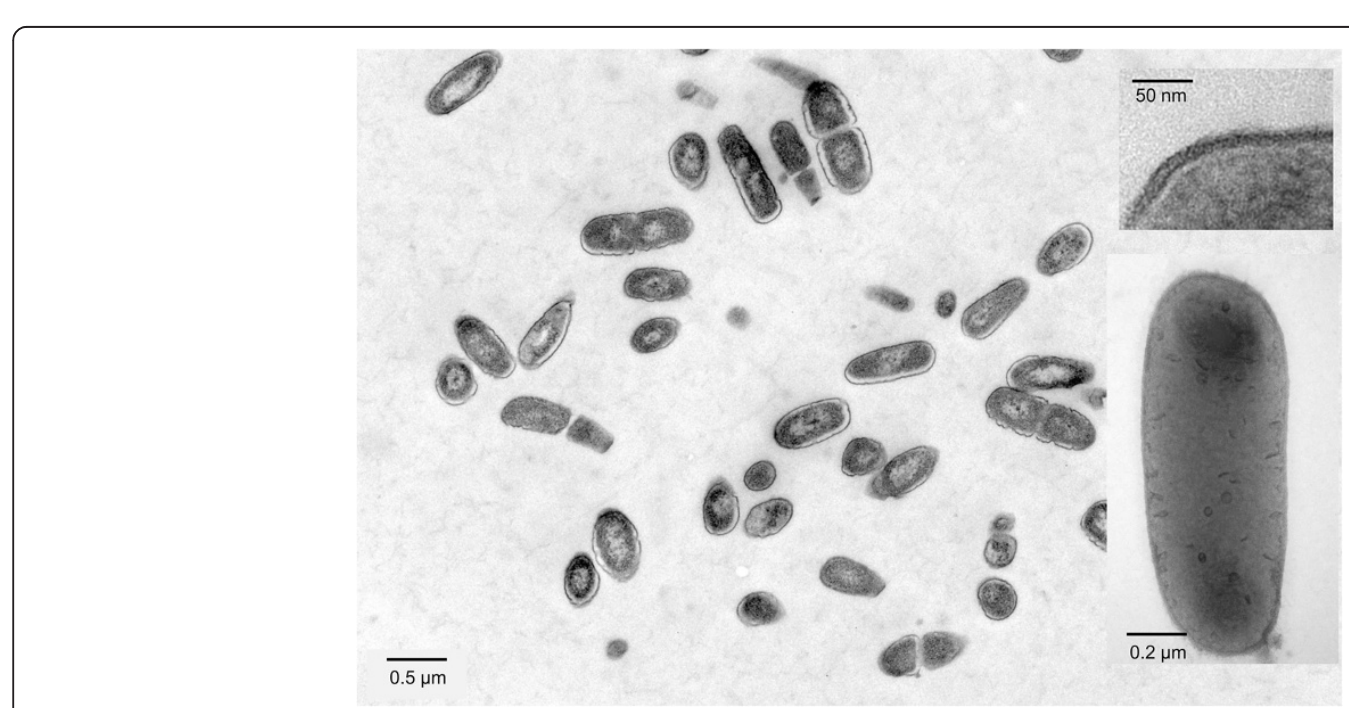

Figure 2 Electron microscopy of $L$. kunkeei EFB6. Large image and upper right inset: stained ultrathin sections; lower right inset: negatively stained single cell (staining salt: uranyl acetate, $4 \%, \mathrm{w} / \mathrm{v})$. 
Table 2 Genome sequencing project information

\begin{tabular}{|c|c|c|}
\hline MIGS ID & Property & Term \\
\hline MIGS-31 & Finishing quality & Improved high-quality draft \\
\hline MIGS-28 & Libraries used & $\begin{array}{l}\text { One Illumina paired-end } \\
\text { library with1 kb insert size }\end{array}$ \\
\hline MIGS-29 & Sequencing platforms & Illumina GAll \\
\hline MIGS-31.2 & Fold coverage & $142.96 \times$ Illumina \\
\hline MIGS-30 & Assemblers & SPAdes 2.5 \\
\hline \multirow[t]{8}{*}{ MIGS-32 } & Gene calling method & YACOP, Glimmer \\
\hline & Locus Tag & LAKU \\
\hline & Genbank ID & AZBY00000000 \\
\hline & GenBank Date of Release & May, 2014 \\
\hline & GOLD ID & Gi0053745 \\
\hline & NCBI project ID & 227106 \\
\hline & BIOPROJECT & PRJNA227106 \\
\hline & Project relevance & Host-associated \\
\hline
\end{tabular}

assembly, we used 2,000,000 paired-end Illumina reads (112 bp) and the SPAdes 2.5 software [27]. The final assembly contained 55 contigs larger than $500 \mathrm{bp}$ and revealed an average coverage of 142.96 .

\section{Genome annotation}

For automatic gene prediction the software tools YACOP [28] and Glimmer [29] were used. Identification of rRNA and tRNA genes was performed by employing RNAmmer [30] and tRNAscan [31], respectively. The annotation provided by the IMG-ER system [32] was corrected manually. For this purpose, data obtained from different databases (Swiss-Prot [33], TrEMBL [34] and InterPro [35]) were used to improve the quality of the annotation.

\section{Genome properties}

The genome statistics are provided in Table 3. The high quality draft genome sequence consists of 55 contigs that account for a total of $1,566,851 \mathrm{bp}$ and a $\mathrm{G}+\mathrm{C}$ content of $37 \mathrm{~mol} \%$. Of the 1,455 predicted genes, 1,417 were putatively protein-encoding, 35 represented putative tRNA genes and three putative rRNA genes. For the majority of the protein-encoding genes $(75 \%)$ a function could be assigned. The distribution of these genes into COG functional categories [36] is shown in Table 4.

\section{Insights into the genome}

Five different Lactobacillus species were used for genome comparisons with L. kunkeei EFB6 based on blastp [37]. Results are shown in Figure 3. All five species are of interest as probiotics, part of the gastrointestinal tract of animals or humans, or used in the production of fermented food.

The identification of orthologous proteins was performed with the program Proteinortho 5.04 [39] by using
Table 3 Genome statistics

\begin{tabular}{lr}
\hline Attribute & \multicolumn{1}{c}{ Value } \\
\hline Genome size (bp) & $1,566,851$ \\
DNA coding (bp) & $1,413,077$ \\
DNA G + C (bp) & 578,359 \\
DNA scaffolds & 55 \\
Total genes & 1,455 \\
Protein coding genes & 1,417 \\
RNA genes & 38 \\
Pseudo Genes & 0 \\
Genes in internal clusters & 20 \\
Genes with function prediction & 1,012 \\
Genes assigned to COGs & 1,195 \\
Genes assigned Pfam domains & 1,221 \\
Genes with signal peptides & 62 \\
Genes with transmembrane helices & 419 \\
CRISPR repeats & 0 \\
\hline
\end{tabular}

Table 4 Number of genes associated with the general COG functional categories

\begin{tabular}{lrrll}
\hline Code & Value & \% age & Description \\
\hline A & 137 & 10.57 & Translation, ribosomal structure and biogenesis \\
K & 0 & 0.00 & RNA processing and modification \\
L & 95 & 7.33 & Transcription \\
B & 94 & 7.25 & Replication, recombination and repair \\
D & 0 & 0.00 & Chromatin structure and dynamics \\
& 24 & 1.85 & Cell cycle control, cell division, chromosome \\
V & 18 & 1.39 & Defense mechanisms \\
T & 32 & 2.47 & Signal transduction mechanisms \\
M & 88 & 6.79 & Cell wall/membrane biogenesis \\
N & 10 & 0.77 & Cell motility \\
U & 25 & 1.93 & Intracellular trafficking and secretion \\
O & 45 & 3.47 & Posttranslational modification, protein \\
& & & turnover, chaperones \\
C & 49 & 3.78 & Energy production and conversion \\
G & 67 & 5.17 & Carbohydrate transport and metabolism \\
E & 112 & 8.64 & Amino acid transport and metabolism \\
F & 68 & 5.25 & Nucleotide transport and metabolism \\
H & 34 & 2.62 & Coenzyme transport and metabolism \\
I & 35 & 2.70 & Lipid transport and metabolism \\
P & 61 & 4.71 & Inorganic ion transport and metabolism \\
Q & 13 & 1.00 & Secondary metabolites biosynthesis, \\
& & & transport and catabolism \\
R & 155 & 11.96 & General function prediction only \\
S & 134 & 10.34 & Function unknown \\
- & 260 & 17.87 & Not in CoGs \\
\hline & & & \\
\hline
\end{tabular}




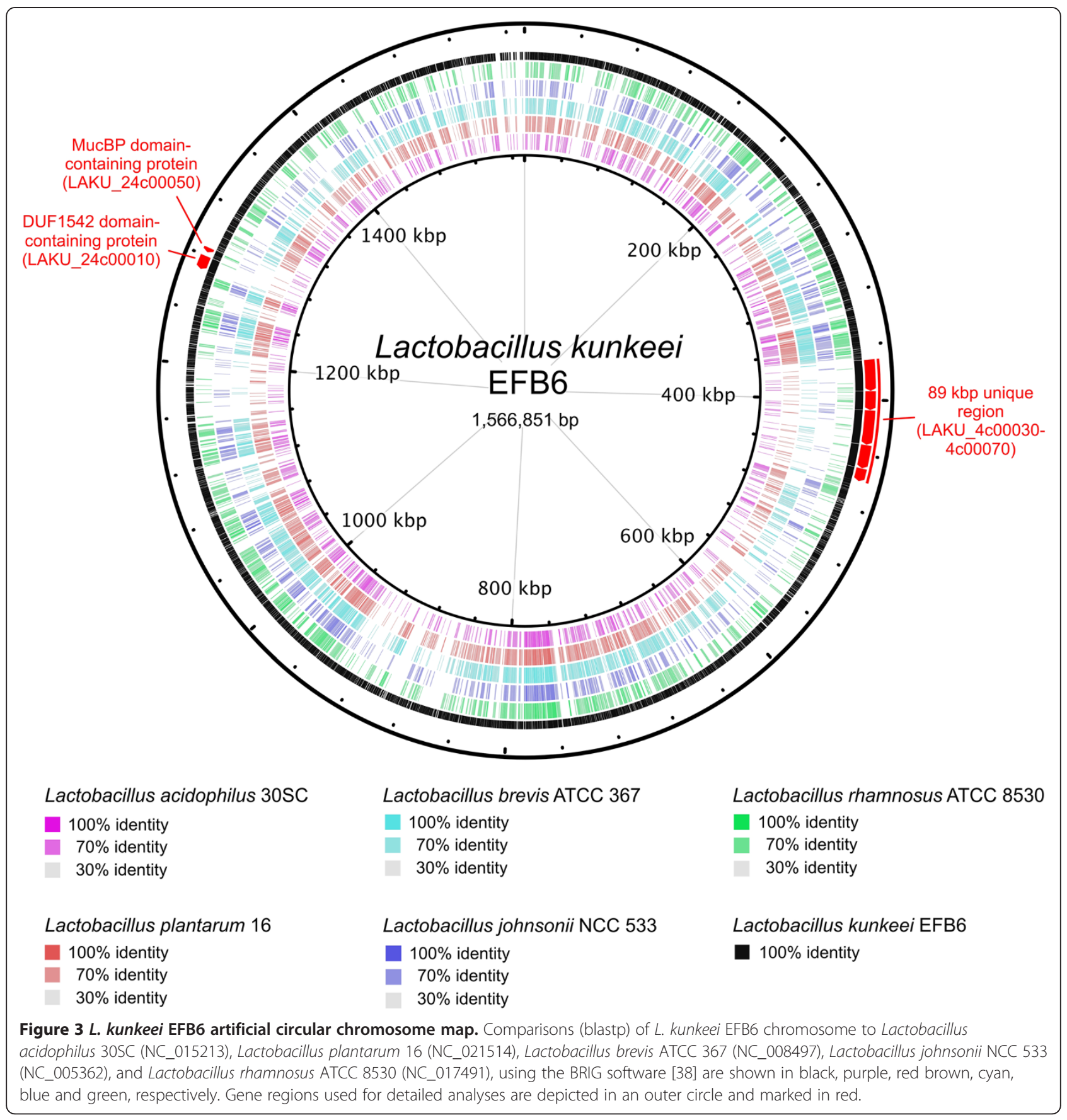

the protein content deduced from 232 lactobacilli genomes as references (GenBank database as of 28.02.2014). For this purpose ncbi_ftp_download v0.2, cat_seq v0.1 and cds_extractor v0.6 were used [40]. With an identity cutoff of 50\%, we identified 425 proteins in L. kunkeei EFB6 without orthologs in any other Lactobacillus species. Among these unique L. kunkeei EFB6 proteins, we selected 7 proteins for detailed analyses.

Analysis of the $89-\mathrm{kb}$ region shown in Figure 3 revealed five ORFs (LAKU_4c00030-LAKU_4c00070) without orthologs in any genomes derived from lactobacilli deposited in GenBank (as of 28.02.2014). Furthermore, no homologs could be identified in any other sequenced microbial genome (NCBI nr-database as of 05.03.2014) by using blastp (e-value cutoff of 1e-20). Except for LAKU_4c00060 (7,521 amino acids), we could identify an N-terminal signal peptide and a noncytoplasmic domain (Figure 4A) using Phobius' domain prediction software [41]: LAKU_4c00040 (4,579 amino acids) and LAKU_4c00070 (3,129 amino acids) contain 


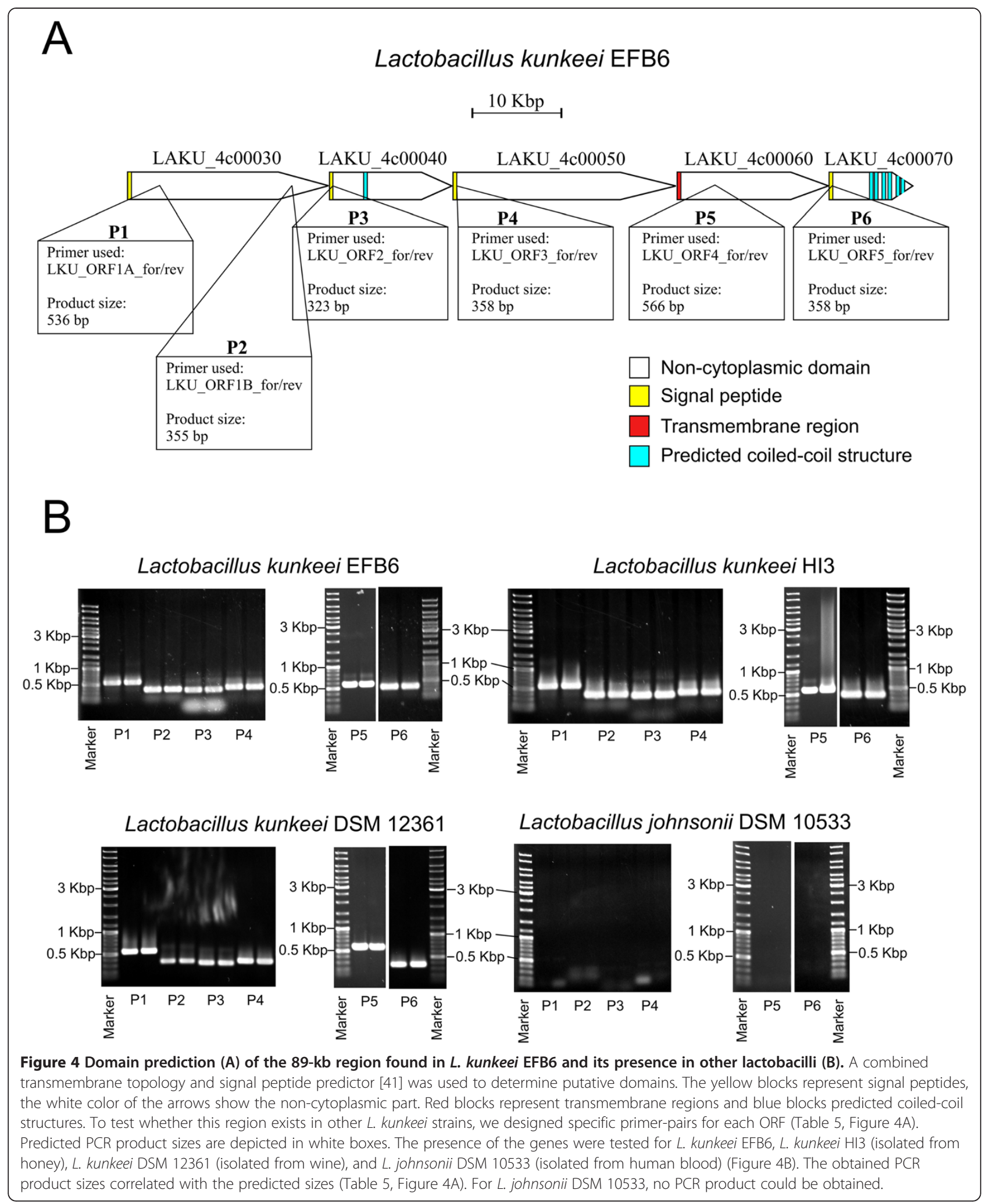

coiled coil structures. Except of LAKU_4c00050 (8,342 amino acids), all ORFs show weak similarity to large surface proteins or extracellular matrix-binding proteins found in bacteria such as Staphylococcus, Streptococcus, Burkholderia, Weissella, Mannheimia, and Marinomonas, but also in Lactobacillus and Pediococcus. Since, $L$. 
Table 5 Primer used in this study

\begin{tabular}{|c|c|c|c|}
\hline Primer & DNA sequence $\left(5^{\prime}-3^{\prime}\right)$ & Open reading frame & Product size \\
\hline LKU_ORF1A_for & AACCAAGAGTAACGATGCCC & LAKU_4C00030 & $536 \mathrm{bp}$ \\
\hline LKU_ORF1A_rev & CTITGGTAATCGGCTTGTGC & & \\
\hline LKU_ORF1B_for & CGATGCACAAACTGCTTACG & LAKU_4c00030 & $355 \mathrm{bp}$ \\
\hline LKU_ORF1B_rev & CATCCTITTGTGCGTCGTTG & & \\
\hline LKU_ORF2_for & AGCTCTITIAGGTGCGTCTG & LAKU_4c00040 & $323 \mathrm{bp}$ \\
\hline LKU_ORF2_rev & TATGCGTCTTGGTGGTTGGC & & \\
\hline LKU_ORF3_for & GCGACTITGTCTGTTITGGG & LAKU_4c00050 & $358 \mathrm{bp}$ \\
\hline LKU_ORF3_rev & ATAGCCCCAGCATATCCAGC & & \\
\hline LKU_ORF4_for & CTACGTTGAGGTTTCCGCTC & LAKU_4c00060 & $566 \mathrm{bp}$ \\
\hline LKU_ORF4_rev & GTTGGAGTTACCTTGCCACC & & \\
\hline LKU_ORF5_for & TCCCAGTAGTAACAAGTAACACC & LAKU_4c00070 & $358 \mathrm{bp}$ \\
\hline LKU_ORF5_rev & AAGCGGTTGATTTCCATTGAC & & \\
\hline
\end{tabular}

kunkeei EFB6 is the first sequenced genome harboring these cluster, we designed specific primer pairs for detection of each ORF in other Lactobacillus strains by PCR (Table 6). As shown in Figure 4B, all five ORFs were present in other L. kunkeei strains isolated from honey and wine. On the basis of domain prediction and IMG's bidirectional best hits [32], we assume that this gene cluster encodes cell surface or secreted proteins involved in cell adhesion or biofilm formation.

During genome comparison, we identified two additional proteins (LAKU_24c00010 and LAKU_24c00050) without a homolog in any of the publicly available genome sequences. These proteins show only weak sequence similarity to known proteins and might be involved in cellular adhesion. LAKU_24c00010 contains a signal peptide, transmembrane helices and 29 DUF1542 domains, which are typically found in cell surface proteins. In Staphylococcus aureus, it has been shown that some DUF1542containing proteins are involved in cellular adhesion and antibiotic resistance [42]. LAKU_24c00010 showed the highest sequence identities to the matrix-binding protein (WP_010490864) of "Lactobacillus zeae" КCTC
3804 (40\%) [43] and the extracellular matrix binding protein (YP_005866289) of Lactobacillus rhamnosus ATCC 53103 (36\%) (Figure 5).

Additionally, LAKU_24c00050 contains N terminal transmembrane helices, two mucin-binding protein domains as well as a $C$ terminal Gram positive-anchoring domain. Proteins with this domain combination are usually associated with bacterial surface proteins. LAKU_24c00050 showed similarity to the Mlp protein (WP_004239242) of Streptococcus mitis and other mucus-binding proteins (Figure 6). Due to the mucosal surface-colonizing properties of lactobacilli, they have been investigated as potential recombinant mucosal vaccines [45].

In the genome of L. kunkeei EFB6, we identified genes encoding all proteins of the general secretory (Sec) pathway and putative polysaccharide biosynthesis proteins, which may participate in capsule or S layer formation. Recently, Butler et al. (2013) [47] detected a lysozyme produced by L. kunkeei Fhon2N and suggested a bacteriolysin or class III bacteriocin function. In L. kunkeei EFB6, we identified four genes belonging to the glycoside hydrolase family 25. Enzymes of this family are known

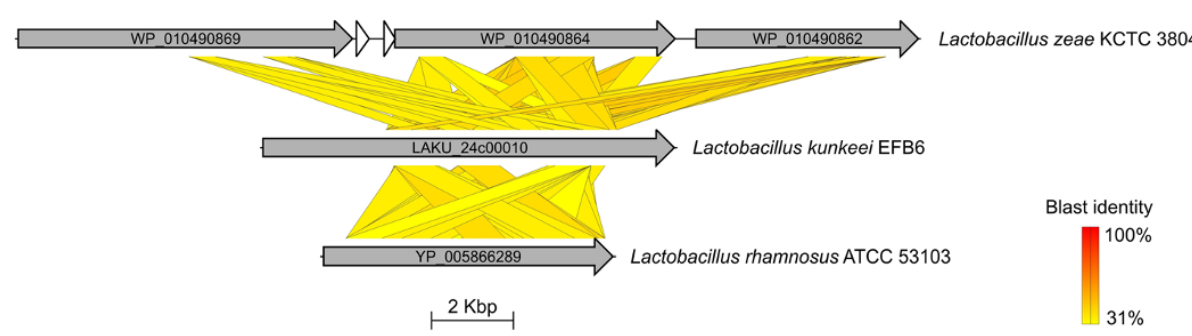

Figure 5 Tblastx comparison of $L$. kunkeei ORF LAKU_24c00010 to matrix binding proteins of L. rhamnosus ATCC 53103 and "L. zeae" KCTC 3804. The graphical presentation was done with Easyfig software (minimum blast hit length of $200 \mathrm{bp}$ and a maximum e-value of $1 \mathrm{e}^{-100}$ ) [44]. LAKU_24c00010 shows similarities to WP_010490869, WP_010490864 and WP_0104908662 of "L. zeae" KCTC 3804 , but also to YP_005866289 (L. rhamnosus ATCC 53103). The ORFs used for comparison are labeled with NCBI accession numbers. The blast identity is shown in a colored scale ranging from $31 \%$ (yellow) to $100 \%$ (red). 


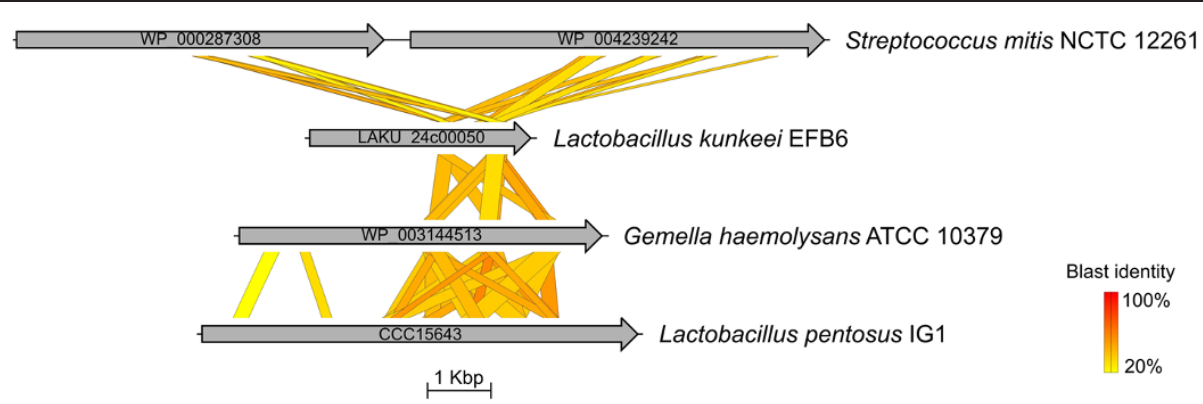

Figure 6 Tblastx comparison of MucBP domain-containing proteins. Comparison of MucBP domain-containing proteins were performed using the program Easyfig (mininum blast hit length of $50 \mathrm{bp}$ and maximum e-value of $1 \mathrm{e}^{-10}$ ) [44]. LAKU_24c00050 shows similarity to ORFs of Streptococcus mitis NCTC 12261 (NCBI accession numbers inside arrows, which represent ORFs used for comparison). Additionally, LAKU_24c00050 shows similarity to WP_003144513 of Gemella haemolysans ATCC 10379 and CCC15643 of Lactobacillus pentosus IG1 [46]. The blast identity is shown in a colored scale ranging from $20 \%$ (yellow) to $100 \%$ (red).

to possess lysozyme activity. Two of the deduced proteins (LAKU_13c00160 and LAKU_32c00010) contain a signal peptide, indicating secretion of the proteins. LAKU_19c00290 harbors transmembrane helices and is probably anchored in the cell wall. LAKU_6c00080 did not contain a putative signal peptide or transmembrane helices.

\section{Rapid test PCR}

Specific primer pairs have been designed to test other strains by PCR for the presence of an $89 \mathrm{~kb}$ region, which harbors five open reading frames (ORFs). Genomic DNA of the L. kunkeei strains EFB6, HI3 and DSM 12361, and Lactobacillus johnsonii DSM 10533 was used as template for PCR amplifications employing the thermal cycler peqSTAR 2X (PEQLAB Biotechnologie GmbH, Erlangen, Germany). PCR amplification was performed with the BIO-X-ACT ${ }^{\mathrm{Tm}}$ Short DNA Polymerase (Bioline, Luckenwalde, Germany) and an initial denaturation step at $98^{\circ} \mathrm{C}$ for $2 \mathrm{~min}$, followed by 30 cycles of denaturation for $20 \mathrm{~s}$ at $96^{\circ} \mathrm{C}$, annealing for $20 \mathrm{~s}$ at $60^{\circ} \mathrm{C}$ and elongation for $30 \mathrm{~s}$ at $68^{\circ} \mathrm{C}$. Subsequently, a final elongation step of $10 \mathrm{~min}$ at $68^{\circ} \mathrm{C}$ was performed. PCR products were purified employing the QIAquick PCR Purification Kit (Qiagen, Hilden, Germany).

\section{Conclusion}

In this study, we characterized the genome of L. kunkeei strain EFB6 isolated from an EFB-diseased larva. In a recent study was shown that $L$. kunkeei has the potential for biofilm formation and adhesion to the honey crop [6]. Our genome analysis supports these results. Using large surface proteins or extracellular matrix-binding proteins, L. kunkeei might be able to attach to eukaryotic epithelial cells. Furthermore, due to the presence of polysaccharide biosynthesis proteins and several enzymes with lysozyme activity, it is possible that $L$. kunkeei is actively protecting its niche against bacterial competitors. As
LABs have been shown to have an inhibitory growth effect on M. plutonius, the use of LABs as probiotic additive against the EFB-causing agent is conceivable.

\section{Additional file}

Additional file 1: Associated MIGS Record.

\section{Abbreviations}

AFB: American foulbrood of honeybees; EFB: European foulbrood of honeybees; LABs: Lactic acid bacteria; TEM: Transmission electron microscopy.

\section{Competing interests}

The authors declare that they have no competing interests.

\section{Authors' contributions}

$M D, A P$ and $R D$ designed research, MD, JS and FJT isolated and characterized strain EFB6, MD, AP and AL carried out genome analyses, MH performed electron microscopy, MD and RD wrote the manuscript with help of AP. All authors read and approved the final manuscript.

\section{Acknowledgements}

We thank the "Bundesministerium für Bildung und Forschung" and the "Niedersächsisches Ministerium für Wissenschaft und Kultur" for support. Additionally, we acknowledge support by the German Research Foundation and the Open Access Publication Funds of the Göttingen University.

\section{Author details}

'Department of Genomic and Applied Microbiology \& Göttingen Genomics Laboratory, Institute of Microbiology and Genetics, Georg-August University of Göttingen, Göttingen, Germany. ${ }^{2}$ Department of General Microbiology, Institute of Microbiology and Genetics, Georg-August University of Göttingen, Göttingen, Germany.

Received: 20 May 2014 Accepted: 4 December 2014 Published: 19 February 2015

\section{References}

1. Klein A-M, Vaissière BE, Cane JH, Steffan-Dewenter I, Cunningham SA, Kremen C, et al. Importance of pollinators in changing landscapes for world crops. Proc R Soc B. 2007;274:303-13.

2. Southwick EE, Southwick Jr L. Estimating the economic value of honey bees (Hymenoptera: Apidae) as agricultural pollinators in the United States. J Econ Entomol. 1992;85:621-33.

3. Forsgren E. European foulbrood in honey bees. J Invertebr Pathol. 2010;103 (Suppl):S5-9. 
4. Djukic M, Brzuszkiewicz E, Fünfhaus A, Voss J, Gollnow K, Poppinga L, et al. How to Kill the Honey Bee Larva: Genomic Potential and Virulence Mechanisms of Paenibacillus larvae. PLoS One. 2014;9:e90914.

5. Bailey L, Collins MD. Reclassification of "Streptococcus pluton" (White) in a new genus Melissococcus, as Melissococcus pluton nom. rev.; comb. nov. J Appl Microbiol. 1982;53:215-7.

6. Vásquez A, Forsgren E, Fries I, Paxton RJ, Flaberg E, Szekely L, et al. Symbionts as major modulators of insect health: lactic acid bacteria and honeybees. PLoS One. 2012;7:e33188.

7. Forsgren E, Olofsson TC, Vásquez A, Fries I. Novel lactic acid bacteria inhibiting Paenibacillus larvae in honey bee larvae. Apidologie. 2009;41:99-108.

8. Olofsson TC, Vásquez A. Detection and identification of a novel lactic acid bacterial flora within the honey stomach of the honeybee Apis mellifera. Curr Microbiol. 2008:57:356-63.

9. Endo A, Irisawa T, Futagawa-Endo Y, Takano K, du Toit M, Okada S, et al. Characterization and emended description of Lactobacillus kunkeei as a fructophilic lactic acid bacterium. Int J Syst Evol Micr. 2012;62:500-4.

10. Edwards CG, Haag KM, Collins MD, Hutson RA, Huang YC. Lactobacillus kunkeei sp. nov.: a spoilage organism associated with grape juice fermentations. J Appl Microbiol. 1998;84:698-702.

11. Woese CR, Kandler O, Wheelis ML. Towards a natural system of organisms: proposal for the domains Archaea, Bacteria, and Eucarya. Proc Natl Acad Sci. 1990:87:4576-9.

12. Gibbons NE, Murray RGE. Proposals Concerning the Higher Taxa of Bacteria. Int J Syst Bacteriol. 1978;28:1-6.

13. Garrity G, Holt J. The Road Map to the Manual. In: Bergey's Manual of Systematic Bacteriology, vol. 1. 2nd ed. New York: Springer; 2001. p. 119-69.

14. Murray R. The Higher Taxa, or, a Place for Everything...? In: Bergey's Manual of Systematic Bacteriology, vol. 1. 1st ed. Baltimore: The Williams and Wilkins Co; 1984. p. 31-4.

15. List Editor. List of new names and new combinations previously effectively, but not validly, published. List no. 132. Int J Syst Evol Microbiol. 2010;60:469-72. doi: 10.1099/ijs.0.022855-0.

16. Ludwig W, Schleifer K, Whitman W. Class I. Bacilli class nov. In: Bergey's Manual of Systematic Bacteriology, Second Edition, Volume 3. New York: Springer; 2009. p. 19-20.

17. Schleifer K, Whitman W. Order II. Lactobacillales ord. nov. In: Bergey's Manual of Systematic Bacteriology, Second Edition, Volume 3 (The Firmicutes). New York: Springer; 2009. p. 464.

18. Skerman V, McGowan V, Sneath P. Approved Lists of Bacterial Names. Int J Syst Bacteriol. 1980;30:225-420.

19. Haakensen M, Dobson C, Hill J, Ziola B. Reclassification of Pediococcus dextrinicus (Coster and White 1964) Back 1978 (Approved Lists 1980) as Lactobacillus dextrinicus comb. nov., and emended description of the genus Lactobacillus. Int J Syst Evol Micr. 2009;59:615-21.

20. Cai Y, Pang H, Kitahara M, Ohkuma M. Lactobacillus nasuensis sp. nov., a lactic acid bacterium isolated from silage, and emended description of the genus Lactobacillus. Int J Syst Evol Micr. 2012;62:1140-4

21. Bergey DH, Breed RS, Hammer BW, Huntoon FM, Murray EGD, Harrison FC. Genus X. Lactobacillus Beijerinck, 191. In: Bergey DH, Breed RS, Hammer BW, Huntoon FM, Murray EGD, Harrison FC, editors. Bergey's Manual of Systematic Bacteriology. 4th ed. Baltimore: The Williams and Wilkins Co; 1934. p. 300-21.

22. Bundesanstalt für Arbeitsschutz und Arbeitsmedizin. Technical rules for biological agents. TRBA 466. Available at: http://www.baua.de/de/ Themen-von-A-Z/Biologische-Arbeitsstoffe/TRBA/TRBA-466.html.

23. Hoppert M. Microscopic Techniques in Biotechnology. Weinheim, FRG: Wiley-VCH Verlag GmbH \& Co. KGaA; 2003. Available at: http://doi.wiley. com/10.1002/3527602615.

24. Mayer F. Cytology and Morphogenesis of Bacteria (Handbook of plant Anatomy IV, 2). Stuttgart: Borntraeger; 1988.

25. Thompson JD, Higgins DG, Gibson TJ. CLUSTAL W: improving the sensitivity of progressive multiple sequence alignment through sequence weighting, position-specific gap penalties and weight matrix choice. Nucleic Acids Res. 1994;22:4673-80

26. Kumar S, Nei M, Dudley J, Tamura K. MEGA: a biologist-centric software for evolutionary analysis of DNA and protein sequences. Brief Bioinform. 2008;9:299-306.

27. Bankevich A, Nurk S, Antipov D, Gurevich AA, Dvorkin M, Kulikov AS, et al. SPAdes: a new genome assembly algorithm and its applications to single-cell sequencing. J Comput Biol. 2012;19:455-77.
28. Tech M, Merkl R. YACOP: Enhanced gene prediction obtained by a combination of existing methods. In Silico Biol. 2003;3:441-51.

29. Delcher AL, Harmon D, Kasif S, White O, Salzberg SL. Improved microbial gene identification with GLIMMER. Nucleic Acids Res. 1999;27:4636-41.

30. Lagesen $\mathrm{K}$, Hallin P, Rødland EA, Staerfeldt H-H, Rognes T, Ussery DW. RNAmmer: consistent and rapid annotation of ribosomal RNA genes. Nucleic Acids Res. 2007;35:3100-8.

31. Lowe TM, Eddy SR. tRNAscan-SE: a program for improved detection of transfer RNA genes in genomic sequence. Nucleic Acids Res. 1997;25:955-64.

32. Markowitz VM, Mavromatis K, Ivanova NN, Chen I-MA, Chu K, Kyrpides NC. IMG ER: a system for microbial genome annotation expert review and curation. Bioinformatics. 2009;25:2271-8

33. Gasteiger E, Jung E, Bairoch A. SWISS-PROT: connecting biomolecular knowledge via a protein database. Curr Issues Mol Biol. 2001;3:47-55.

34. O'Donovan C, Martin MJ, Gattiker A, Gasteiger E, Bairoch A, Apweiler R. High-quality protein knowledge resource: SWISS-PROT and TrEMBL. Brief Bioinform. 2002;3:275-84.

35. Hunter S, Jones P, Mitchell A, Apweiler R, Attwood TK, Bateman A, et al. InterPro in 2011: new developments in the family and domain prediction database. Nucleic Acids Res. 2012;40:D306-12.

36. Tatusov RL, Fedorova ND, Jackson JD, Jacobs AR, Kiryutin B, Koonin EV, et al. The COG database: an updated version includes eukaryotes. BMC Bioinformatics. 2003:4:41.

37. Altschul SF, Gish W, Miller W, Myers EW, Lipman DJ. Basic local alignment search tool. J Mol Biol. 1990;215:403-10.

38. Alikhan NF, Petty NK, Ben Zakour NL, Beatson SA. BLAST Ring Image Generator (BRIG): simple prokaryote genome comparisons. BMC Genomics. 2011;12:402.

39. Lechner M, Findeiss S, Steiner L, Marz M, Stadler PF, Prohaska SJ. Proteinortho: detection of (co-)orthologs in large-scale analysis. BMC Bioinformatics. 2011;12:124.

40. Leimbach A. bac-genomics-scripts. 2014. Available at: https://github.com/ aleimba/bac-genomics-scripts.

41. Käll L, Krogh A, Sonnhammer EL. A combined transmembrane topology and signal peptide prediction method. J Mol Biol. 2004;338:1027-36.

42. Clarke SR, Harris LG, Richards RG, Foster SJ. Analysis of Ebh, a 1.1megadalton cell wall-associated fibronectin-binding protein of Staphylococcus aureus. Infect Immun. 2002;70:6680-7.

43. Dicks LMT, Du Plessis EM, Dellaglio F, Lauer E. Reclassification of Lactobacillus casei subsp. casei ATCC 393 and Lactobacillus rhamnosus ATCC 15820 as Lactobacillus zeae nom. rev., designation of ATCC 334 as the neotype of L. casei subsp. casei, and rejection of the name Lactobacillus paracasei. Int J Syst Bacteriol. 1996;46:337-40.

44. Sullivan MJ, Petty NK, Beatson SA. Easyfig: a genome comparison visualizer. Bioinformatics. 2011;27:1009-10.

45. Turner MS, Hafner LM, Walsh T, Giffard PM. Peptide surface display and secretion using two LPXTG-containing surface proteins from Lactobacillus fermentum BR11. Appl Environ Microbiol. 2003:69:5855-63.

46. Zanoni P, Farrow JAE, Phillips BA, Collins MD. Lactobacillus pentosus, (Fred, Peterson and Anderson) sp. nov., nom. rev. Int J Syst Bacteriol. 1987;37:339-41.

47. Butler E, Alsterfjord M, Olofsson TC, Karlsson C, Malmström J, Vásquez A. Proteins of novel lactic acid bacteria from Apis mellifera mellifera: an insight into the production of known extra-cellular proteins during microbial stress. BMC Microbiol. 2013;13:235.

doi:10.1186/1944-3277-10-16

Cite this article as: Djukic et al: High quality draft genome of

Lactobacillus kunkeei EFB6, isolated from a German European foulbrood outbreak of honeybees. Standards in Genomic Sciences 2015 10:16. 